IJTI (International Journal Of Transportation And Infrastructure)
Available Online @ $\mathrm{http}: / /$ ju mal .na rota ma.ac.id/index.php/ijti
ISSN : 2597-4769 (ONUNE) ISSN : 2597-4734 (CETAK)

Volume 2 Number 1 September 2018

\title{
ANALYSIS OF THE EFFECT OF ADDITION OF INJECTION PLASTIC SEEDS (HDPE), QUARTZ SAND AND ADDITIVE TO CONCRETE MIXTURE
}

\author{
Tjatur Rahmadi Maulana ${ }^{1}$, Fredy Kurniawan². \\ University of Narotama, Surabaya \\ tjaturrahmadi@gmail.com
}

\begin{abstract}
Plastic material is one of many materials that are difficult to decompose naturally and require hundreds of years to decompose completely. One way to reduce the volume of plastic waste is to process or recycle it. Plastic injection seeds (HDPE) is one type of processed plastic waste (HDPE). In this study using the concrete laboratory experimental method according to SNI 03-2834-2000. There are 2 stages in this concrete research, stage 1 is concrete with variations of quartz sand $(20 \%, 30 \%$, and $40 \%)$ to the weight of sand and the most optimum results are obtained in concrete mix with $40 \%$ quartz sand and $3 \%$ additive (TH1 / 40-28) which is equal to $613.1 \mathrm{~kg} \mathrm{/} \mathrm{cm} 2$ in the 28 day test, an increase of $42.34 \%$ from the compressive strength of normal concrete K300 of 430.73 $\mathrm{kg} / \mathrm{cm} 2$. For phase 2, concrete with a variation of quartz sand is $40 \%$ and the addition of coarse aggregates from plastic seeds (HDPE) (20\%,30\% and 40\%) from the weight of gravel and find the most optimal results of concrete mix with $40 \%$ quartz, plastic $20 \%$, additive $3 \%$ (TH2 / 20-28) which is equivalent to $359.5 \mathrm{~kg} / \mathrm{cm} 2$ in a 28 day test, a decrease of $41.4 \%$ from the compressive strength of concrete stage 1 quartz sand $40 \%$ (TH1 / 40-28) from $613,1 \mathrm{~kg} / \mathrm{cm} 2$.
\end{abstract}

Key words: hdpe plastic seeds; quartz sand; additive; compressive strength; concrete.

\section{INTRODUCTION}

Developments in the construction sector are currently progressing very rapidly. This is inseparable from the demands and needs of the community for increasingly advanced infrastructure, such as bridges with long spans, tall buildings and other facilities. Concrete is one of the choices as a basic structural material in building construction. In general, concrete consists of cement, fine aggregates, coarse aggregates and water. But along with the development of science and technology, the composition of the concrete mixture also changed.

One example is the inclusion of added ingredients or substitutes in concrete. Utilization of plastic waste for concrete mixtures is one step to reduce plastic waste problems that until now have not been overcome. Plastic waste has several advantages, namely having a light weight, not easy to change shape, and also has a weakness that is 
Volume 2 Number 1 September 2018

having a slippery surface and very difficult to decompose by nature, this often leads to environmental pollution.

From such problems arises a thought for the research of mixing concrete using artificial aggregates from waste plastic (HDPE) with, quartz sand and additive materials. The purpose of this study was to determine the behavior of the value of compressive strength of concrete with a mixture of artificial aggregate from plastic waste (HDPE) as a partial substitute for the total gross weight of the aggregate. The results of this study are very useful as one of the references for the manufacture of lightweight concrete materials using mixed waste materials so that they can be utilized in infrastructure development such as buildings and others.

\section{RESEARCH METHODS}

\section{A. Material}

The materials to be used in this study include:

Portland cement Type 1 (PCC) Brand: Semen Gresik, Natural Sand (Lumajang), Quartz Sand, Rough Aggregates Type: Broken Stone (Split), Water, HDPE Injection Plastic Seeds Size: $4 \times 2 \mathrm{~mm}$ (flat oval), Additive Additon Superplast 23F Size: $0.4-2 \%$ of the weight of cement

\section{B. Standard Operating Procedure}

1. Prepare split aggregates, sand, and cement according to the job mix then mix evenly.

2. Add half a dose of water (F.A.S $0.3-0.35 \%$ of the weight of the cement and stir until smooth).

3. Pour the measured Additon Superplast liquid (0.4 - 3\% Additon Superplast from the weight of the cement to mix the concrete $1 \mathrm{~m}^{3}$ ) gradually while stirring evenly, finally add the remaining water until the mixture becomes homogeneous (slightly dry).

4. Concrete is ready for use.

5. Important: Do not add Additon Superplast directly to the cement.

Tabel 1. Mixed Design Formula

\begin{tabular}{|c|c|c|c|c|c|c|c|c|c|c|c|c|c|c|}
\hline \multirow{2}{*}{ Description } & \multirow{2}{*}{\multicolumn{2}{|c|}{ Cement }} & \multirow{2}{*}{\multicolumn{2}{|c|}{$\begin{array}{c}\text { Sand } \\
\text { Lumajang }\end{array}$}} & \multirow{2}{*}{\multicolumn{2}{|c|}{$\begin{array}{l}\text { Sand } \\
\text { Quartz }\end{array}$}} & \multirow{2}{*}{\multicolumn{2}{|c|}{ Gravel }} & \multirow{2}{*}{\multicolumn{2}{|c|}{ Plastik }} & \multirow{2}{*}{$\begin{array}{c}\text { Water Cement } \\
\mathbf{0 , 3}\end{array}$} & \multirow{2}{*}{\multicolumn{2}{|c|}{\begin{tabular}{|c|}
$\begin{array}{c}\text { Additif Additon } \\
\text { Superplast } 23 \mathrm{~F}\end{array}$ \\
$\begin{array}{c}\mathbf{3} \% \text { from } \\
\text { weight of } \\
\text { ce ment }\end{array}$
\end{tabular}}} & \\
\hline & & & & & & & & & & & & & & \\
\hline Normal Concrete k 300 & 566,7 & $\mathrm{~kg}$ & $1.149,0$ & $\mathrm{~kg}$ & - & $\mathrm{kg}$ & 766,0 & $\mathrm{~kg}$ & - & $\mathrm{kg}$ & 170,0 & $\mathrm{~L}$ & 17,0 & $\mathrm{~L}$ \\
\hline & & & & & & & & & & & & & & \\
\hline $\mathrm{TH} 1 / 20$ & 566,7 & $\mathrm{~kg}$ & 919,2 & $\mathrm{~kg}$ & 229,8 & $\mathrm{~kg}$ & 766,0 & $\mathrm{~kg}$ & - & $\mathrm{kg}$ & 170,0 & $\mathrm{~L}$ & 17,0 & $\mathrm{~L}$ \\
\hline $\mathrm{TH} 1 / 30$ & 566,7 & $\mathrm{~kg}$ & 804,3 & $\mathrm{~kg}$ & 344,7 & $\mathrm{~kg}$ & 766,0 & $\mathrm{~kg}$ & - & $\mathrm{kg}$ & 170,0 & $\mathrm{~L}$ & 17,0 & $\mathrm{~L}$ \\
\hline $\mathrm{TH} 1 / 40$ & 566,7 & $\mathrm{~kg}$ & 689,4 & $\mathrm{~kg}$ & 459,6 & $\mathrm{~kg}$ & 766,0 & $\mathrm{~kg}$ & - & $\mathrm{kg}$ & 170,0 & $\mathrm{~L}$ & 17,0 & $\mathrm{~L}$ \\
\hline $2 / 20$ & 5667 & $\mathrm{ko}$ & & $1 \sigma_{\sigma}$ & 4596 & $1 / \sigma_{0}$ & 6128 & $1<0$ & 153 & $v_{\sigma}$ & 170 & I & 10 & I \\
\hline TH2/30 & 566,7 & $\mathrm{~kg}$ & 689,4 & $\mathrm{~kg}$ & 459,6 & $\mathrm{~kg}$ & 536,2 & $\mathrm{~kg}$ & 229,8 & $\mathrm{~kg}$ & 170,0 & $\mathrm{~L}$ & 17,0 & $\mathrm{~L}$ \\
\hline $\mathrm{TH} 2 / 40$ & 566,7 & $\mathrm{~kg}$ & 689,4 & $\mathrm{~kg}$ & 459,6 & $\mathrm{~kg}$ & 459,6 & $\mathrm{~kg}$ & 306,4 & $\mathrm{~kg}$ & 170,0 & $\mathrm{~L}$ & 17,0 & $\mathrm{~L}$ \\
\hline
\end{tabular}


Volume 2 Number 1 September 2018

Table 2. Total Test Objects

\begin{tabular}{|c|c|c|c|}
\hline \multirow{2}{*}{ Test Object Samples } & \multicolumn{3}{|c|}{ Concrete Age } \\
\cline { 2 - 4 } & 7 days & 14 days & 28 days \\
\hline Normal Concrete k 300 & 2 & 2 & 2 \\
\hline & & & \\
\hline $\mathrm{TH} 1 / 20$ & 2 & 2 & 2 \\
\hline $\mathrm{TH} 1 / 30$ & 2 & 2 & 2 \\
\hline $\mathrm{TH} 1 / 40$ & 2 & 2 & 2 \\
\hline & & & 2 \\
\hline $\mathrm{TH} 2 / 20$ & 2 & 2 & 2 \\
\hline $\mathrm{TH} 2 / 30$ & 2 & 2 & 2 \\
\hline $\mathrm{TH} 2 / 40$ & 2 & 2 & 14 \\
\hline Total & 14 & 14 & \\
\hline Total cylindrical mold test specimens: 15 Height: $30 \mathrm{~cm}$, \\
42 pieces used. \\
\hline
\end{tabular}

After the fresh concrete reaches homogeneous, slump testing is carried out. At the stage of maintenance of the test object, carried out after a day's age by immersing the test object in the curing tub for 7 days.

Compressive strength testing was carried out on specimens aged 7, 14 and 28 days, after the drying process from the treatment of specimens. Compressive strength testing was carried out in the Civil Engineering and concrete laboratory of Narotama University Surabaya.

\section{RESULTS AND DISCUSSION}

Fine and coarse aggregate testing includes humidity, specific gravity, volume weight, cleanliness, sieving, as follows:

\section{A. Analysis of Lumajang Sand and Quartz Sand}

Table 3. Testing of Fine Aggregates

\begin{tabular}{|c|c|c|c|c|}
\hline \multirow{2}{*}{ No. } & \multirow{2}{*}{ Testing } & \multirow{2}{*}{ Unit } & \multicolumn{2}{|c|}{ Fine aggregate } \\
\cline { 4 - 5 } & & & $\begin{array}{c}\text { Sand } \\
\text { Lumajang }\end{array}$ & $\begin{array}{c}\text { Sand } \\
\text { Quartz }\end{array}$ \\
\hline 1 & Sludge levels & & & \\
\hline \multirow{4}{*}{} & a. Sedimentation & $\%$ & 0,01 & 0,01 \\
\cline { 4 - 5 } & b. Washing & $\%$ & 5,74 & 0,43 \\
\cline { 2 - 5 } & & & & \\
\hline 2 & SSD Specific Gravity & $\mathrm{gr} / \mathrm{cm} 3$ & 2,25 & 2,75 \\
\hline 3 & Moisture Sand & $\%$ & 8,18 & 0,90 \\
\hline 4 & Absorption & $\%$ & 1,24 & 1,21 \\
\hline & & & & \\
\hline 5 & Volume Weight & 49 & & \\
\hline \multirow{2}{*}{} & a. Without pressure & $\mathrm{gr} / \mathrm{cm} 3$ & 1,23 & 1,32 \\
\hline & b. With pressure & $\mathrm{gr} / \mathrm{cm} 3$ & 1,71 & 1,68 \\
\hline & c. With sway & $\mathrm{gr} / \mathrm{cm} 3$ & 1,26 & 1,46 \\
\hline
\end{tabular}


IJTI (International Journal Of Transportation And Infrastructure) Available Online @ http://jumal.na rota ma.ac.id/index.php/ijti ISSN : 2597-4769 (ONUNE) ISSN : 2597-4734 (CETAK)

Volume 2 Number 1 September 2018 
IJTI (International Journal Of Transportation And Infrastructure) Available Online @ http://jumal.na rota ma.ac.id/index.php/ijti ISSN : 2597-4769 (ONUNE) ISSN : 2597-4734 (CETAK)

Volume 2 Number 1 September 2018

\section{B. Gravel Analysis}

Table 4. Testing of Rough Aggregates

\begin{tabular}{|c|c|c|c|}
\hline \multirow{2}{*}{ No. } & \multirow{2}{*}{ Testing } & \multirow{2}{*}{ Unit } & Rough Aggregate \\
\cline { 4 - 4 } & & & Gravel \\
\hline 1 & Sludge levels & & \\
\hline & & $\%$ & 2,20 \\
\cline { 3 - 4 } & a. Washing & & \\
\hline 2 & SSD Specific Gravity & $\mathrm{gr} / \mathrm{cm} 3$ & 2,41 \\
\hline 3 & Moisture Stone & $\%$ & 2,78 \\
\hline 4 & Absorption & $\%$ & 5,49 \\
\hline & & & \\
\hline 5 & Volume Weight & & \\
\hline \multirow{2}{*}{} & a. Without pressure & $\mathrm{gr} / \mathrm{cm} 3$ & 1,40 \\
\hline & b. With pressure & $\mathrm{gr} / \mathrm{cm} 3$ & 1,54 \\
\hline
\end{tabular}

\section{Aggregate Analysis of HDPE Injection Plastic Seeds}

Has a flat round shape with dimensions of $4 \times 2 \mathrm{~mm}$, slippery plastic surface.

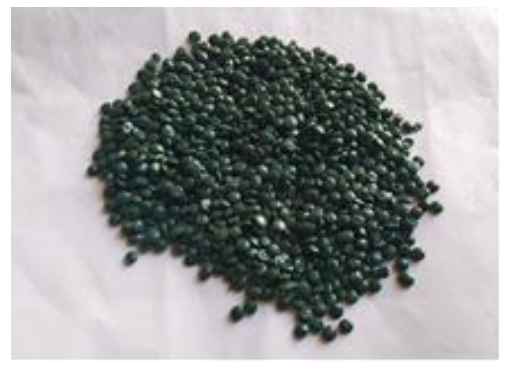

Picture 1: Aggregate of HDPE Injection Plastic Seeds 
Volume 2 Number 1 September 2018

\section{Results and Comparison of Concrete Press Strength}

Table 5 Results of Testing Phase 1 Concrete Compressive Strength Stage 1 (Concrete Aggregate Mixture of Quartz Sand 20\%, 30\%, 40\% and Additive Superplast Add 3\%).

\begin{tabular}{|c|c|c|c|c|c|}
\hline No & Concrete type & $\mathbf{K N}$ & MPA & $\begin{array}{c}\text { Concrete Press } \\
\text { Strength } \\
(\mathrm{kg} / \mathrm{cm} 2)\end{array}$ & $\begin{array}{l}\text { Specific } \\
\text { gravity } \\
(\mathrm{kg} / \mathrm{m} 3)\end{array}$ \\
\hline 1 & $\begin{array}{c}\text { Normal Concrete } \\
\text { K300 - } 7 \text { days }\end{array}$ & 407,5 & 23,1 & 283,1 & $2.296,9$ \\
\hline 2 & $\begin{array}{l}\text { Normal Concrete } \\
\text { K300 - } 14 \text { days }\end{array}$ & 547,5 & 31,0 & 380,4 & $2.292,8$ \\
\hline 3 & $\begin{array}{c}\text { Normal Concrete } \\
\text { K300 - } 28 \text { days }\end{array}$ & 620,0 & 35,1 & 430,7 & $2.315,5$ \\
\hline 1 & $\begin{array}{c}\text { Concrete Stage 1, Quartz } \\
\text { Sand } 20 \% \text { TH1/20 - } 7 \text { days } \\
\end{array}$ & 392,5 & 22,2 & 272,7 & $2.243,8$ \\
\hline 2 & $\begin{array}{c}\text { Concrete Stage 1, Quartz } \\
\text { Sand 20\% TH1/20 - } 14 \text { days }\end{array}$ & 590,0 & 33,4 & 409,9 & $2.242,8$ \\
\hline 3 & $\begin{array}{c}\text { Concrete Stage 1, Quartz } \\
\text { Sand } 20 \% \mathrm{TH} 1 / 20-28 \text { days } \\
\end{array}$ & 662,5 & 37,5 & 460,3 & $2.317,5$ \\
\hline 1 & $\begin{array}{c}\text { Concrete Stage 1, Quartz } \\
\text { Sand } 30 \% \text { TH1/30 - } 7 \text { days }\end{array}$ & 515,0 & 29,1 & 357,8 & $2.246,4$ \\
\hline 2 & $\begin{array}{c}\text { Concrete Stage 1, Quartz } \\
\text { Sand } 30 \% \text { TH1/30 - } 14 \text { days }\end{array}$ & 690,0 & 39,0 & 479,4 & $2.245,0$ \\
\hline 3 & $\begin{array}{c}\text { Concrete Stage 1, Quartz } \\
\text { Sand 30\% TH1/30 - } 28 \text { days }\end{array}$ & 777,5 & 44,0 & 540,2 & $2.303,1$ \\
\hline 1 & $\begin{array}{c}\text { Concrete Stage 1, Quartz } \\
\text { Sand } 40 \% \text { TH1/40 - } 7 \text { days }\end{array}$ & 732,5 & 41,4 & 508,9 & $2.247,9$ \\
\hline 2 & $\begin{array}{c}\text { Concrete Stage 1, Quartz } \\
\text { Sand } 40 \% \text { TH1/40 - } 14 \text { days }\end{array}$ & 822,5 & 46,5 & 571,4 & $2.317,5$ \\
\hline 3 & $\begin{array}{c}\text { Concrete Stage 1, Quartz } \\
\text { Sand } 40 \% \text { TH1/40 - } 28 \text { days }\end{array}$ & 882,5 & 49,9 & 613,1 & $2.284,3$ \\
\hline
\end{tabular}




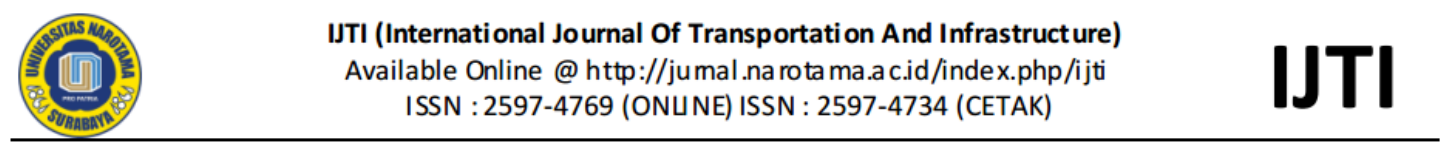

Volume 2 Number 1 September 2018

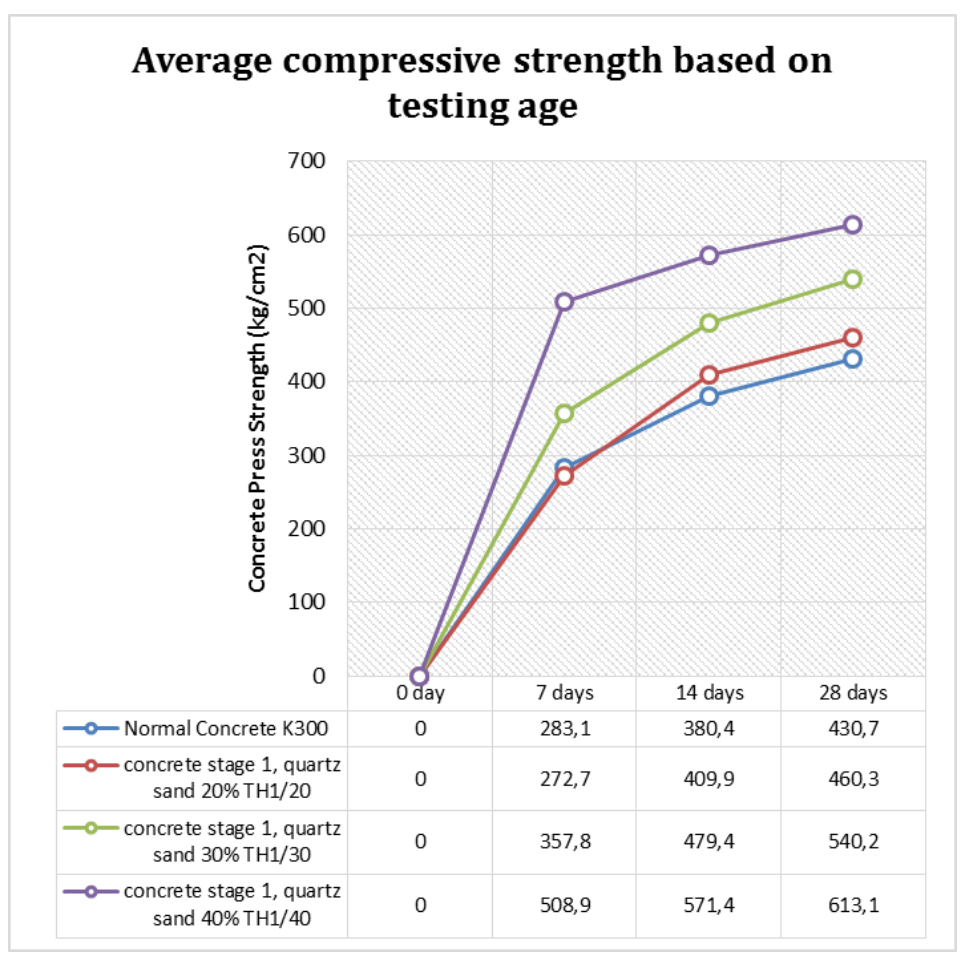

Chart 1 Shows the Increased Press Strength of the Combined Concrete Between Normal Concrete With Concrete Stage 1, Based on Testing Age 7, 14, 28 Days.

From Graph 1 above shows the compressive strength of normal K300 concrete with stage 1 concrete (TH1) with a mixture of quartz sand $20 \%, 30 \%$, and $40 \%$. At the time of testing, the largest value of compressive strength of concrete was found in the stage 1 concrete mixture with quartz sand $40 \%$ and Additive Superplast 23F 3\% from the weight of cement (TH1 / 40-28) which is equal to $613.1 \mathrm{~kg} / \mathrm{cm} 2$ at 28 days testing , there was an increase of $42.34 \%$ from the normal concrete compressive strength of K300 of $430.73 \mathrm{~kg}$ / $\mathrm{cm} 2$.

This proves that there is an increase in the strength of concrete along with the increasing composition of the mixture of quartz sand $(20 \%, 30 \%$, and $40 \%)$ even though the levels of cement and additives are the same.

It can be concluded that the design of normal K300 concrete mixtures and concrete using quartz sand with additive mixture of Additon Superplast 23F does not have a significant impact on mass weight and specific gravity. 
Volume 2 Number 1 September 2018

Table 6 Results of Phase 2 Concrete Compressive Strength Test

Stage 2 (Aggregate Concrete Mixture 40\% Quartz Sand, HDPE Plastic 20\%, 30\%, 40\%, and Superplast Additives 3\%)

\begin{tabular}{|c|c|c|c|c|c|}
\hline No & Concrete type & $\mathbf{K N}$ & MPA & $\begin{array}{c}\text { Concre te Press } \\
\text { Strength } \\
(\mathrm{kg} / \mathrm{cm} 2) \\
\end{array}$ & $\begin{array}{l}\text { Specific } \\
\text { gravity } \\
(\mathrm{kg} / \mathrm{m} 3) \\
\end{array}$ \\
\hline 1 & $\begin{array}{c}\text { Concrete Stage 1, Quartz } \\
\text { Sand } 40 \% \text { TH1/40 - } 7 \text { days }\end{array}$ & 732,5 & 41,4 & 508,9 & $2.247,9$ \\
\hline 2 & $\begin{array}{c}\text { Concrete Stage 1, Quartz } \\
\text { Sand } 40 \% \text { TH1/40 - } 14 \text { days }\end{array}$ & 822,5 & 46,5 & 571,4 & $2.317,5$ \\
\hline 3 & $\begin{array}{c}\text { Concrete Stage 1, Quartz } \\
\text { Sand } 40 \% \text { TH1/40 - } 28 \text { days }\end{array}$ & 882,5 & 49,9 & 613,1 & $2.284,3$ \\
\hline 1 & $\begin{array}{c}\text { Concrete Stage 2, Plastic } \\
\text { Seeds 20\% TH2/20 - } 7 \text { days }\end{array}$ & 430,0 & 24,3 & 298,7 & $2.070,2$ \\
\hline 2 & $\begin{array}{c}\text { Concrete Stage 2, Plastic } \\
\text { Seeds 20\% TH2/20 - } 14 \text { days }\end{array}$ & 465,0 & 26,3 & 323,1 & $2.079,5$ \\
\hline 3 & $\begin{array}{c}\text { Concrete Stage } 2 \text {, Plastic } \\
\text { Seeds } 20 \% \text { TH } 2 / 20 \text { - } 28 \text { days }\end{array}$ & 517,5 & 29,3 & 359,5 & $2.075,6$ \\
\hline 1 & $\begin{array}{c}\text { Concrete Stage 2, Plastic } \\
\text { Seeds } 30 \% \mathrm{TH} 2 / 30-7 \text { days }\end{array}$ & 397,5 & 22,5 & 276,2 & $2.001,6$ \\
\hline 2 & $\begin{array}{c}\text { Concrete Stage } 2 \text {, Plastic } \\
\text { Seeds } 30 \% \text { TH2/30 - } 14 \text { days }\end{array}$ & 435,0 & 24,6 & 302,2 & $2.004,0$ \\
\hline 3 & $\begin{array}{c}\text { Concrete Stage } 2 \text {, Plastic } \\
\text { Seeds } 30 \% \text { TH2/30 - } 28 \text { days }\end{array}$ & 465,0 & 26,3 & 323,1 & $1.991,4$ \\
\hline 1 & $\begin{array}{c}\text { Concrete Stage } 2 \text {, Plastic } \\
\text { Seeds } 40 \% \text { TH2/40 - } 7 \text { days }\end{array}$ & 347,5 & 19,7 & 241,4 & $1.954,9$ \\
\hline 2 & $\begin{array}{c}\text { Concrete Stage } 2 \text {, Plastic } \\
\text { Seeds } 40 \% \mathrm{TH} 2 / 40 \text { - } 14 \text { days }\end{array}$ & 370,0 & 20,9 & 257,1 & $1.956,0$ \\
\hline 3 & $\begin{array}{c}\text { Concrete Stage } 2 \text {, Plastic } \\
\text { Seeds } 40 \% \text { TH2/40 - } 28 \text { days }\end{array}$ & 417,5 & 23,6 & 290,1 & $1.957,2$ \\
\hline
\end{tabular}


Volume 2 Number 1 September 2018

Chart 2 Shows the Increased Press Strength of the Combined Concrete Between Concrete Stage 1 (40\% Quartz Variation) With Stage 2 Concrete (Plastic Variation) Based on Testing Age 7, 14, 28 Days

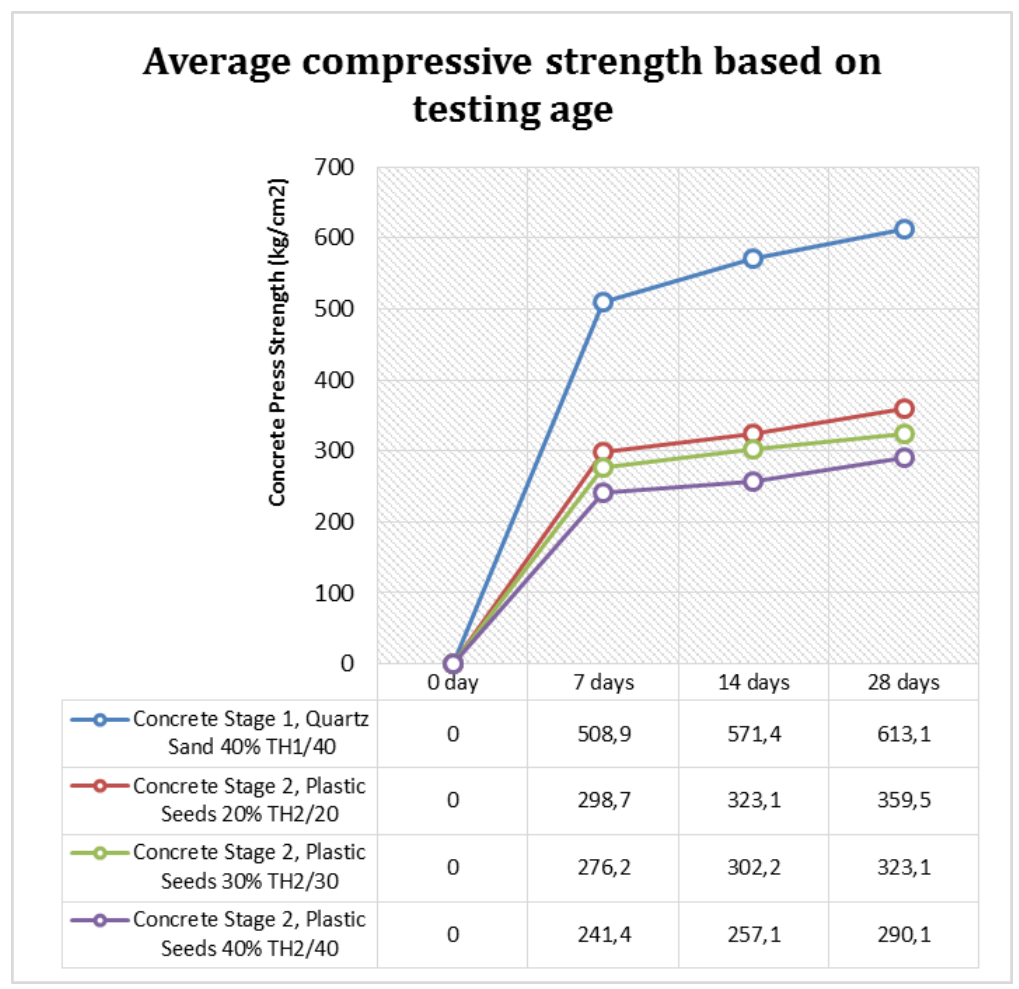

From Graph 2 above shows the compressive strength of concrete stage 1 quartz sand $40 \%$ (TH1 / 40) with concrete stage 2 (TH2) mixed $20 \%, 30 \%$, and $40 \%$. At the time of testing, the value of the largest concrete compressive strength was found in concrete mixtures with $40 \%$ quartz sand, $20 \%$ plastic aggregate, and $23 \mathrm{~F}$ Superplast Additives of $3 \%$ by weight of cement (TH2 / 20-28) which is $359.5 \mathrm{~kg} / \mathrm{cm} 2$ in the test 28 days, there was a $41.4 \%$ decrease in stage 1 concrete compressive strength of quartz sand $40 \%$ ( $\mathrm{TH} 1$ / 40-28) of $613.1 \mathrm{~kg} / \mathrm{cm} 2$.

This proves that there is a decrease in the strength of concrete along with the increasing composition of the mixture of HDPE plastic aggregates $(20 \%, 30 \%$, and $40 \%)$ even though the levels of cement, sand and additives are the same. There is a decrease in mass and specific gravity weight as the composition of the mixture of HDPE plastic aggregates increases $(20 \%, 30 \%$, and $40 \%)$ despite the same levels of cement, sand and additives. 
Volume 2 Number 1 September 2018

\section{CONCLUSION}

Based on the results of research and discussion, conclusions can be taken as follows:

1. In the mixed design stage 1 , the optimum concrete compressive strength was achieved in a mixture of $40 \%$ quartz sand from the weight of sand, and 23pl Superplast $3 \%$ of the weight of cement (TH1 / 40-28) which was $49.9 \mathrm{MPa}$ using a cylindrical specimen $\varnothing 15 \mathrm{~cm} \times 30 \mathrm{~cm}$ with a drop value of $4 \mathrm{~cm}$. So the mixed design (TH1 / 40) is used as the basis for the mixed design stage 2 .

2. In the mixed design stage 1 optimal concrete compressive strength values were achieved in a mixture of $40 \%$ quartz sand from sand weight, $20 \%$ HDPE plastic from gravel weight, and 23F 3\% Superplast additives from cement weight (TH2 / 20-28) which is $29,3 \mathrm{MPa}$ with slump $4 \mathrm{~cm}$. So that it can be categorized as high quality concrete K300 (29.4 MPa).

3. The use of additives added by the Additon Superplast $23 \mathrm{~F}$ brand must use the ideal amount of water, because if too much water will occur blending and segregation. Concrete dough like pasta, concrete mixture quickly hardens so that the concrete mixing work is heavier.

\section{SUGGESTION}

From the description above and referring to the results of the study, to get better research results, the following are suggested by researchers:

1. For similar studies, it is necessary to change HDPE plastic aggregate using artificial plastic or aggregates which are melted and crushed, because researchers have used HDPE plastic seed aggregates that are flat round and have dimensions of $4 \times 2$ $\mathrm{mm}$.

2. For the use of HDPE plastic seed aggregates as lightweight walls it is not recommended, because if the concrete is damaged or perforated there will be a concrete collapse which results in severe damage to the concrete..

\section{BIBLIOGRAPHY}

Alfiandi, Dhiyando Giovanni. et al. The Effect of PET Plastic Waste Usage as Coarse Aggregates on Lightweight Concrete Structures. Thesis. Not published.

Antonius. et al. Effectiveness of Quartz Sand as Fine Aggregate. Proceedings of the National Seminar - Policies and Strategies in Infrastructure Development \& Regional Development Based on Green Technology. Civil Engineering Department, Sultan Agung Islamic University. 
Volume 2 Number 1 September 2018

Aprieli, Krisman. et al. Effect of Addition of Silica Smoke and Superplasticizer on HighQuality Concrete Press Strength with the Aci Method (American Concrete Institute). Civil Engineering Department, University of North Sumatra.

Kasiati, Endang. et al. Changes in the Strength of Optimal Concrete Compression in the Composition of Silica Sand Mixtures with Waste Sand. Proceedings of the National Infrastructure Technology Application Seminar (ATPW), Surabaya, July 11, 2012.

Mulyono, T. 2004. Concrete Technology, Andi, Yogyakarta.

Murdock, L.J. and Brook, K.M., Concrete Materials and Practices, 4th Edition, translated into Indonesian by Ir. Stephanus Hendarko, Erlangga Publisher, Jakarta, 1999.

Nadia. et al. Effect of Silica Level on Fine Aggregate Concrete Mixes. Construction Journal Volume 3 December 1, 2011. Civil Engineering Department, Muhammadiyah University Jakarta. 